\title{
An isolated site of calciphilous lichens in the Kujawy region
}

\author{
Mirosława Ceynowa-Giełdon, Edyta Adamska*, Dariusz Kamiński \\ Nicolaus Copernicus University, Faculty of Biology and Environment Protection, Chair of Geobotany and Landscape \\ Planning, Lwowska 1, 87-100 Toruń, Poland, \\ * e-mail: adamska@umk.pl
}

\begin{abstract}
The paper presents a list of lichen species occurring in three quarries and on mine dumps located within the dust emission impact zone of the cement plant "Kujawy". The species occur in the lowlands far from their natural localities on limestone rocks in southern Poland. The study area is therefore a valuable habitat island for epilithic and epigeic species of calciphilous lichens in central Poland. Particularly noteworthy are taxa characteristic of natural limestone rocks found in mountain areas of Poland: Verrucaria calciseda, Verrucaria nigroumbrina V. obfuscans and $V$. polysticta, as well as nine species from the Polish Red List of Lichens: Bacidia rubella, Caloplaca cf. cerina, Enchylium coccophorum, Endocarpon pusillum, Heppia adglutinata, Lempholema chalazanum, Goidanichia ambrosiana, Thelidium incavatum and Th. papulare.
\end{abstract}

Key words: biodiversity, lichenized fungi, endangered species, calciphilous lichens, Kujawy, environmental island, anthropopression, anthropogenic habitats.

\section{Introduction}

Human impact on the landscape is usually manifested in its fragmentation, followed by simplification of the vegetation structure, which leads to the degradation and loss of habitats and consequently biodiversity decline (cf. Fahrig, 2003; Fischer \& Lindenmayer, 2007). In some cases, however, man creates new semi-natural habitats, which do not occur spontaneously in a given area. Their presence extends the range of many groups of organisms. Examples of such habitats include old quarries and waste dumps of lime industry in the Kujawy region. They are particularly valuable in lichenological terms as they represent habitat islands with specific calciphile lichen biota comprising a number of rare lowland species. This is an example of human impact on the distribution and dispersion of lichens that enables colonization of new regions by these organisms (cf. Wirth, 1995).

The research aimed at taxonomic classification of lichens occurring in the study area, description of their biota and habitat preferences as well as a compiled list of lichen species identified so far in this area.

\section{Study area}

The research was conducted in the area of the Wapienno Mining Plant (excavation pits in Wapienno and Bielawy together with external dumping grounds), i.e. the limestone quarry Lafarge Holcim Cement S.A., the Division in Bielawy, located on the upland plain in the north-eastern part of the Gniezno Lakeland (Kondracki, 2009), about $20 \mathrm{~km}$ west of Inowrocław (Fig. 1). The area of quarries stretches over approximately $6 \mathrm{~km}$ between Wapienno and Piechcin, at the south-western side of provincial road no. 251 (route Żnin - Inowrocław). It consists of three, currently connected excavation pits. The largest, working pit located in Wapienno stretches as an irregular strip in the south-easterly direction and connects with the older quarry situated in Bielawy, which turns into the third excavation pit located 
in Piechcin. The width of the investigated zone is up to ca. $1 \mathrm{~km}$. High mine waste dumps are located next to the quarries; they consist mostly of clay relocated during limestone exposure. Smaller areas are covered by waste lime dumps. Dumping grounds, similarly to the excavation pits, are exposed to human impact of varying intensity. Some of them are covered by newly excavated material, while others are left to natural succession. The whole study area is heavily contaminated with lime dust released not only by the pits, but mostly by the "Kujawy" cement plant located in the immediate vicinity of the quarries.

Limestone mining has begun within the discussed area in 1860 (Czajkowski, 1969) and has been connected with a tectonic uplift referred to as the Central-Polish Anticlinorium or the Kuyavian-Pomeranian anticline. Large blocks of Jurassic limestone are buried beneath a relatively thin layer of boulder clay $(3-10 \mathrm{~m})$ on the SW slope of this major uplift; they are exposed to a depth of $60-100 \mathrm{~m}$. Crevices, karst caves and dolomites can be observed on the walls of the quarries. Dolomites occur in the form of veins and irregular pockets with a diameter ranging from a few to several metres (Passendorfer \& Wilczyński, 1961).
Study sites:

1. Quarry in Wapienno (52 $\left.49^{\prime} 54^{\prime \prime} \mathrm{N} 17^{\circ} 58^{\prime} 34^{\prime \prime} \mathrm{E}\right)$

2. Dumps in Wapienno (52 $\left.49^{\prime} 50^{\prime \prime} \mathrm{N} 17^{\circ} 57^{\prime} 38^{\prime \prime} \mathrm{E}\right)$

3. Quarry in Bielawy (52 $\left.49^{\circ} 08^{\prime \prime} \mathrm{N} 18^{\circ} 00^{\prime} 32^{\prime \prime} \mathrm{E}\right)$

4. Quarry in Piechcin (52 $\left.48^{\prime} 52^{\prime \prime} \mathrm{N} 18^{\circ} 01^{\prime} 45^{\prime \prime} \mathrm{E}\right)$.

According to the symbols used in the ATPOL system of grid squares (Zając, 1978), the study area is located within square CC56.

\section{Materials and methods}

Taxonomic material was collected in the course of fieldwork conducted in 1994-1998 as well as in 2004 and 2006. The study material consisted mostly of specimens of epilithic lichens growing on old walls of quarries and epigeic lichens collected on mine dumps and stacking yards. In addition, relatively rare specimens of epiphytic lichens collected from the bark of trees growing along access roads and other places adjacent to the quarries were also identified.

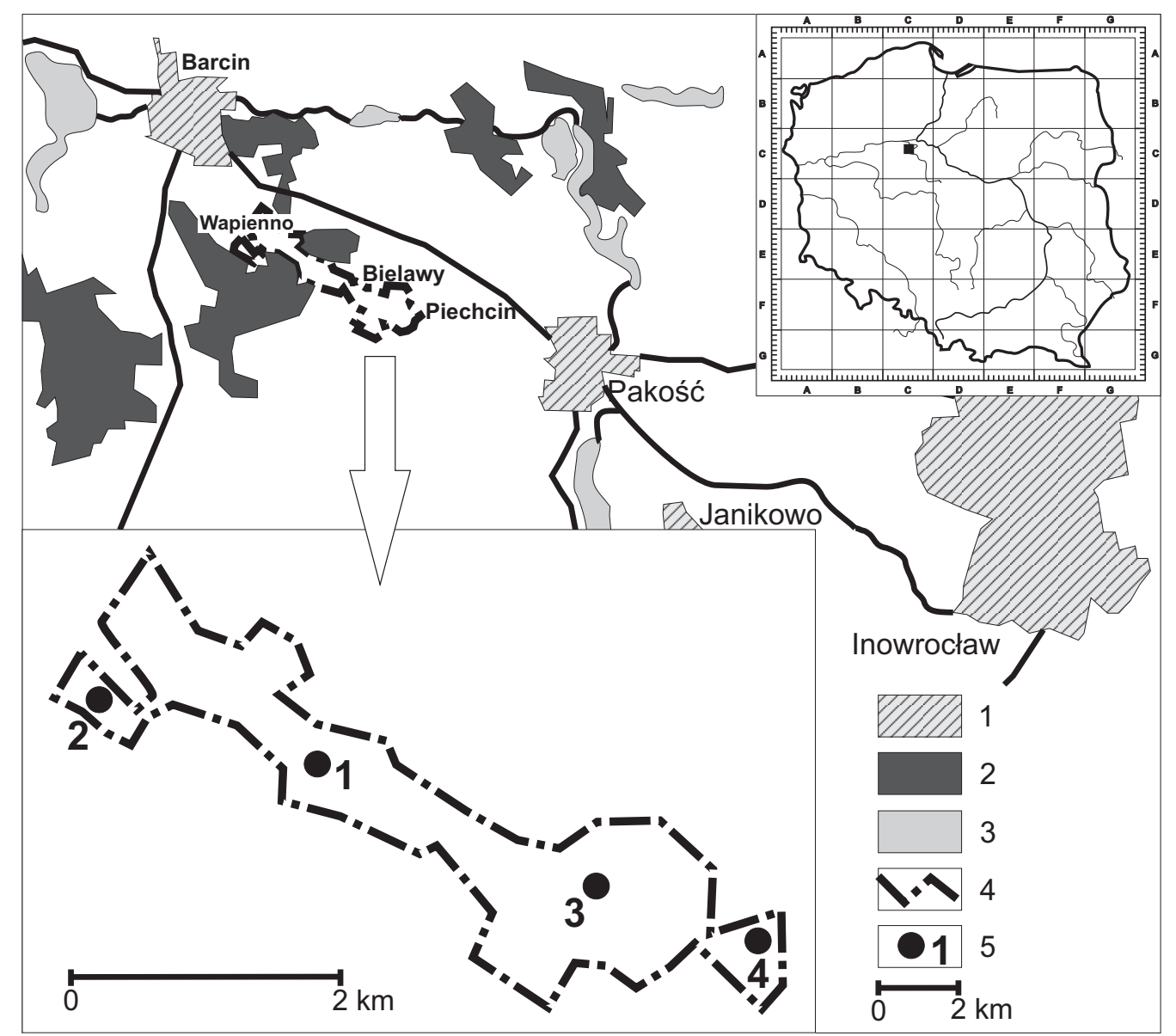

Figure 1. Location of the research area and study sities; 1 - towns and cities, 2 - forests, 3 - lakes, 4 - quarry border, 5 - study sities (1 - Quarry in Wapienno, 2 - Dumps in Wapienno, 3 - Quarry in Bielawy, 4 - Quarry in Piechcin) 
Lichens were identified using several identification keys, e.g. Purvis et al. (1994), Wirth (1995), Smith et al. (2009), Nowak \& Tobolowski (1975). Identification of species from the genus Verrucaria was based mainly on the work by Krzewicka (2012).

The list of species provides: the site name, the frequency of occurrence, the type of substrate, habitat and the category of threat. Categories of threat were determined according to the Red List of Threatened Lichens in Poland (Cieśliński et al. 2006): EN - Endangered, VU - Vulnerable, NT - Near Threatened.

The frequency of occurrence of individual taxa was assessed as: very rare, rare, relatively rare, frequent, relatively common and common.

The collected material was deposited at the Herbarium of Nicolaus Copernicus University in Torun (TRN).

Nomenclature of species followed mostly the Index Fungorum (2016) database and Fałtynowicz \& Kossowska (2016). Nomenclature for Collemataceae was used according to Otálora et al. (2014), for the genus Verrucaria (Krzewicka, 2012), except for Verrucaria calciseda.

\section{Results and discussion}

A total of 53 lichen species were found in the study area, including epilithic, epigeic and epiphytic lichens. Given the size of the study area, the identified biota of lichens is relatively large. For comparison, 57 calciphilous species were reported from northern Poland (Sągin,1998), 160 taxa of epilithic calciphilous lichens were identified on naturally exposed rocks in the Kraków-Wielun Upland (Nowak, 1967), 152 species in the Pieniny Mountains (Tobolewski, 1958) and 153 species in the Western Tatras (Olech, 1985).

\section{List of species}

1. Acarospora moenium (Vain.) Räsänen [syn. Aspicilia moenium (Vain.) G. Tor \& Timdal] - Wapienno, Bielawy, frequent on limestone and metal in the upper parts of the quarries, near industrial buildings.

2. Athallia holocarpa (Hoffm.) Arup, Frödén \& Søchting [syn. Caloplaca holocarpa (Hoffm.) A.E. Wade] - Wapienno, Bielawy, Piechcin, relatively common, on rocks and bark of Salix spp.

3. Bacidia rubella (Hoffm.) A. Massal. - Wapienno rare, on the bark of Salix spp., near the mine dump, VU.

4. Bilimbia sabuletorum (Schreb.) Arnold [syn. Myxobilimbia sabuletorum (Schreb.) Hafellner] - Piechcin, Bielawy, scattered, on mosses and bare soil.

5. Blennothallia crispa (Weber ex F.H. Wigg.) Otálora, P.M. Jørg. \& Wedin [syn. Collema crispum (Huds.) Weber in F.H. Wigg. var. crispum] - Wapienno, Bielawy, Piechcin, common, on the ground, limestone and mosses covered with a thick layer of dust, usually in the barren form adapted to vegetative propagation.

6. Buellia griseovirens (Turner \& Borrer ex Sm.) Almb. Wapienno, rare, on the bark of Salix spp., at the mine dump.

7. Caeruleum heppii (Nägeli ex Körb.) K. Knudsen \& Arcadia [syn. Acarospora heppii (Naeg. in Hepp) Naeg. in Körb.] - Wapienno, rare, on small pebbles collected on the mine dump.

8. Calogaya decipiens (Arnold) Arup, Frödén \& Søchting [Caloplaca decipiens (Arnold) Blomb. \& Forss.] Wapienno, Bielawy Piechcin - common, on limestone, in sunlit places.

9. Caloplaca saxicola (Hoffm) Nordin] - Piechcin, frequent on long-exposed limestone.

10. Caloplaca cf. cerina (Hedw.) Th. Fr. - Bielawy, rare, VU.

11. Candelariella aurella (Hoffm.) Zahlbr. - Wapienno, Bielawy, Piechcin - common, on sunlit limestone and bark of trees (Populus spp., Salix spp.).

12. Clauzadea monticola $\mathrm{cf}$. (Ach.) Hafellner \& Bellem. Wapienno.

13. Flavoplaca citrina (Hoffm.) Arup, Frödén \& Søchting [syn. Caloplaca citrina (Hoff.) Th.Fr.] - Piechcin, rare, recorded on a concrete pillar.

14. Enchylium coccophorum (Tuck.) Otálora, P.M. Jørg. \& Wedin [syn. Collema coccophorum Tuck.] - Bielawy, Piechcin, relatively common on the ground, on a small elevated surface, on the western side of tracks and access roads of the quarry, EN.

15. Enchylium limosum (Ach.) Otálora, P.M. Jørg. \& Wedin [syn. Collema limosum (Ach.) Ach.] - Wapienno, Bielawy, Piechcin, relatively common on the ground and weathering rock waste, along the roads and on the mine dumps.

16. Enchylium tenax (Sw.) Gray - Piechcin, relatively common on small dumps surrounding the quarry from the west and south.

17. Endocarpon pusillum Hedw. - Bielawy Piechcin, relatively common on mosses and humus soil, in sunny places, on the edge of quarries, VU.

18. Goidanichia ambrosiana (A. Massal.) Tomas. \& Cif. [syn. Staurothele ambrosiana (A. Massal.) Zschacke] - Piechcin, very rare on small stones covering the limestone waste heap, VU.

19. Heppia adglutinata (Kremp.) A. Massal. [syn. Heppia lutosa (Ach.) Nyl.] - Piechcin, collected once in a small rock crevice, on the western wall of the quarry, EN.

20. Lecania erysibe (Ach.) Mudd - Bielawy, Piechcin, relatively common on limestone, in dry and sunny places.

21. Lecidella stigmatea (Ach.) Hertel \& Leuckert - Piechcin, rare on limestone. 
22. Lempholemma chalazanum (Ach.) B. de Lesd. - Piechcin, relatively rare, on old mine dumps and calcareous soil in the near and further vicinity of the quarry, e.g. at the fence of the stadium, NT.

23. Leptogium byssinum (Hoffm.) Zwackh ex Nyl. - Wapienno, on a high waste dump and on the roadsides, in some places abundant and scattered over a large area, at others difficult to find.

24. Mycobilimbia tetramera (De Not.) Vitik., Ahti, Kuusinen, Lommi \& T. Ulvinen ex Hafellner \& Türk [syn. M. fusca (A. Massal.) Hafellner] - Wapienno, rare, amidst mosses in the lower part of the quarry.

25. Myriolecis albescens (Hoffm.) Śliwa, Zhao Xin \& Lumbsch [syn. Lecanora albescens (Hoffm.) Flörke] - Wapienno, Bielawy, Piechcin, common on limestone along edges of quarries.

26. Myriolecis dispersa (Pers.) Śliwa, Zhao Xin \& Lumbsch [syn. Lecanora dispersa (Pers.) Sommerf.] - Wapienno, Bielawy, Piechcin same as M. albescens.

27. Myriolecis hagenii (Ach.) Śliwa, Zhao Xin \& Lumbsch [syn. Lecanora hagenii (Ach.) Ach.] - Wapienno, Bielawy, Piechcin, common on trees and shrubs of the study area, especially on the bark of Salix spp.

28. Parmelia sulcata Taylor - Wapienno, Bielawy, Piechcin, common on trees and shrubs of the study area, especially on the bark of Salix spp. and Pinus sylvestris.

29. Peltigera rufescens (Weiss) Humb. - Bielawy Zachodnie, rare, amidst mosses, on the land elevation.

30. Phaeophyscia nigricans (Flörke) Moberg - Wapienno, rare on the bark of Salix spp.

31. Phaeophyscia orbicularis (Neck.) Moberg - Wapienno, Bielawy, Piechcin, frequent, on limestone and bark of trees.

32. Physcia adscendens (Fr.) H. Olivier - Piechcin, relatively rare, on limestone with a thick layer of dust.

33. Physcia tenella (Scop.) DC., in Lamarck \& de Candolle - same as Ph. adscendens.

34. Protoblastenia rupestris (Scop.) J. Steiner - Wapienno, relatively common but over a small area on a steep, unexploited wall of the quarry overgrown with Pinus sylvestris.

35. Sarcogyne regularis Körb. - Bielawy, rare, on the eastern wall of the quarry receiving large amounts of sunlight.

36. Thelidium incavatum Nyl. ex Mudd - Wapienno, Piechcin, rare, on a wall slightly shaded by trees, in the lower part of the quarry, in the place which has not been exploited for more than 20 years. Specimens from Wapienno identified as Th. incavatum have spores smaller than the average size presented in the descriptions of this species and a large percentage of degenerated spores. The size of spores is similar to $T h$. corconticum Servít (1954), of unclear taxonomic rank, described from the Czech Karkonosze Mountains (Ceynowa-Giełdon \& Adamska, 2014), NT.

37. Thelidium papulare (Fr.) Arnold - Wapienno, Piechcin, rare, on an old, unexploited wall of the quarry, accompanied by Th. incavatum (Ceynowa-Giełdon \& Adamska, 2014), NT.

38. Thelidium rimosulum Ceyn.-Giełd. - Bielawy, Piechcin, rare, on long-exposed limestone in the western part of the study area. Piechcin (isotyp) (Ceynowa-Giełdon, 2007; cf. Ceynowa-Giełdon \& Adamska, 2014).

39. Thelidium zwackhii (Hepp) A. Massal. - Wapienno, Piechcin, rare, on a dump and in the lower part of the excavation pit with water (Ceynowa-Giełdon \& Adamska, 2014).

40. Verrucaria aethiobola Wahlenb. [syn. Verrucaria cataleptoides (Nyl.) Nyl.] - Piechcin, on a dump, (22.09.1994, 23.9.1994). Wapienno - at the quarries (13.07.1993); (det. Beata Krzewicka). Reported from Carpathians and North Poland (Krzewicka, 2012).

41. Verrucaria bryoctona (Th. Fr.) Orange - Piechcin, very rare, on the ground, near the road at the south-eastern side of the limestone excavation pit. According to Krzewicka (2012), the species grows on basic soil.

42. Verrucaria calciseda DC. [syn. Bagliettoa calcise$d a$ (DC.) Gueidan \& Cl. Roux] - Piechcin, rare, on long-exposed limestone, in the warm place with a direct sunlight (17.10.2006).

43. Verrucaria dolosa Hepp - western part of Bielawy.

44. Verrucaria maculiformis Kremp. - Bielawy, Piechcin, between the quarries, together with $V$. nigrescens i $V$. muralis.

45. Verrucaria muralis Ach. - Wapienno, Bielawy, Piechcin, common on sunny rocks and small stones.

46. Verrucaria nigroumbrina (A. Massal.) Servit - Wapienno, in the excavation pit of the quarry, Bielawy, Piechcin, on long-exposed limestone (13.07.1993); (det.Beata Krzewicka). According to Krzewicka (2012), this taxon is known in Poland from a few locations in the Carpathians.

47. Verrucaria nigrescens Pers. - Wapienno, Bielawy, Piechcin, common in places with direct sunlight, on long-exposed limestone, sometimes in the barren form with soredia.

48. Verrucaria obfuscans Nyl. - western part of Bielawy, Piechcin, rare on long-exposed limestone, in sunny and warm places.

49. Verrucaria cf. policensis Servit - Bielawy, collected on a waste heap (4.09.1993); (det. Beata Krzewicka).

50. Verrucaria polysticta Borrer [syn. V. subfuscella Nyl.] - Wapienno, on an old, unexploited wall of the quarry (4.04.2004). According to Krzewicka (2012), the species occurs in areas with large natural limestone outcrops e.g. the Kraków-Częstochowa Upland. 
51. Verrucaria tectorum (A.Massal.) Korb - Wapienno, at the bottom of the quarry, at a long-exposed wall, together with $V$. muralis. (det. Beata Krzewicka).

52. Verrucaria viridicans Servit - Piechcin, collected in the limestone excavation pit (8.08.1995); (det. Beata Krzewicka). The taxon is known in Poland only from the Kraków-Wielun Upland (Krzewicka, 2012).

53. Xanthoria parietina (L.) Th. Fr - Wapienno, Bielawy, Piechcin, common on trees and shrubs of the study area, especially on the bark of Salix spp.

It is also very interesting to compare the capacity of lichens from the discussed group for colonizing the anthropogenic habitats. As described by Saqgin (1998), the dispersion mode of taxa might be an important aspect in this process of colonization. Most species of lichens colonizing anthropogenic rock substrates produce numerous apothecia, while species characteristic of natural habitats produce mostly barren thalli with isidia.

On the naturally exposed limestone rocks in the southern part of Poland, lichens are represented by a larger number of species compared to artificial substrates with similar properties. As reported by Pietrzykowska and Kossowska (2010), in the Polish part of the Karkonosze Mountains where there are no natural limestone rocks, calciphilous lichens occur on anthropogenic limestone substrates which result from the construction of mountain hostels. A total of 28 calciphilous lichen species were found there. As described by Szczepańska (2008), a total of 170 species were identified on the rock substrates in the Śnieżnik Massif and in the Bialskie Mountains. Twenty two species were identified on natural outcrops of limestone rocks in Kleśnica (e.g. Acarospora cervina, Dermatocarpon miniatum, Scytinium gelatinosum [syn. Leptogium gelatinosum]), and only 8 species on rocks in a marble quarry. Like in Wapienno, Szczepańska (2008) found Clauzadea monticola and Protoblastenia rupestris on the rocks of the quarry in Kleśnica. The species also occurred on the surface of concrete poles and ruins of buildings. On the other hand, Collema tenax and Sarcogyne regularis were found by Szczepańska only on the natural substrate in the quarry and on the rock outcrops.

Twenty five epilithic lichen species were found in the Świętokrzyski National Park and in the buffer zone on natural limestone substrates (rocks of Zapusty). Twenty nine taxa were described from artificial bedrock. Circinaria contorta [syn. Aspicilia contorta], among others, as well as the above-mentioned taxa: Dermatocarpon miniatum and Protoblastenia rupestris (Łubek, 2007) occurred only on natural rocks.

According to Fałtynowicz (1992), calciphilous lichens (mainly Myriolecis dispersa, Candelariella aurella, Myriolecis albescens, Phaeophyscia orbicularis) occur in Western Pomerania on anthropogenic substrates connected with urban areas and containing calcium carbonate. These pioneer species with a wide ecological amplitude were also found on natural and artificial substrates in the Polish Sudetes (Kossowska, 2008).

Due to the varying intensity of human impact, no lichens or only their initial barren thalli occur over a large area of the strip limestone mine in Kujawy. However, not only the direct mining activity is unfavourable for many lichens. Much more harmful to lichens is pollution generated by dust emission from the large cement plant located in the immediate vicinity of the mine. For this reason, several components of the lichen biota occur in the described area often in a very impoverished form, with a large percentage of degenerated spores.

A different time elapsed since the exposure of limestone substrates makes it possible to follow the succession process of lichens. Crustose species from the genera Verrucaria and Thelidium are the first to colonize the limestone. They are represented by very rare species: Thelidium rimosulum - previously described from Piechcin (Ceynowa-Giełdon, 2007) as well as Th. incavatum and Th. papulare (cf. Ceynowa-Giełdon \& Adamska, 2014) observed for the first time in the Kujawy region far from their natural sites located in the uplands and mountains in the southern part of Poland (Fałtynowicz, 2003). The genus Verrucar$i a$ is represented by a larger number of species, including Verrucaria muralis and V. nigrescens - common in Poland, encountered on artificial habitats, often in urban areas (e.g. Adamska, 2014). Less common are Verrucaria aethiobo$l a$ and $V$. tectorum. - known also from the lowland and mountain areas, as well as $V$. nigroumbrina, $V$. obfuscans, $V$. polysticta, $V$. cf. policensis and $V$. viricans - for the first time collected in Kujawy, far from their natural locations on limestones in the southern part of Poland (Fałtynowicz, 2003; Krzewicka, 2012). In addition, species new to Kujawy include also Verrucaria calciseda. For comparison, Christensen \& Alstrup (2013) reported only one species from the genus Verrucaria $-V$. muralis on e.g. limestone rock outcrops in the mountains of northern Greece.

Among more or less common species from the genus Verrucaria, the following species common in Poland: Candelariella aurella, Myriolecis dispersa, Myriolecis albescens, Calogaya decipiens, Calogaya pusilla and species from the genus Phaeophyscia and Sarcogyne regularis occur in large numbers on sunlit, long-exposed rocks at the quarries of the study area. Barren thalli of Acarospora moenium were observed on the most polluted rocks and metal scraps near industrial buildings.

Species growing on the ground, on dusty mosses and plant debris, on mine waste dumps and rock debris are a separate group of lichens characteristic of areas adjacent to the limestone mines in Kujawy. They are represented mainly by taxa from the family Collemataceae, including the most common Blennothallia crispa-formerly regarded 
as a variety typical of the taxon Collema crispum, and less common C. crispum var. metzleri. Another common lichen in the study area was Enchylium limosum - a widespread species in the Kujawy region (Ceynowa-Giełdon, 2001; Ceynowa-Giełdon et al., 2004). Less frequently encountered representatives of the family Collemataceae include: Enchylium coccophorum, E. tenax, Leptogium byssinum and Lempholemma chalazanum. In warm places exposed to the direct sunlight, thalli of Endocarpon pusillum were relatively common in addition to species from the genus Blennothallia and Enchylium. Also Heppia adglutinata was found in the area - a very rare species in Poland.

Epiphytic species, i.e. the most sensitive to air pollution are least represented in the local biota of lichens. Common calciphilous species, e.g. Athallia holocarpa, Candelariella aurella and Phaeophyscia orbicularis - encountered in Poland both on natural rocks and artificial limestone habitats, as well as on the bark of trees and shrubs with more or less alkaline reaction - were found in the study area mainly on the bark of trees and shrubs growing near the mine. As a result of heavy lime dust in the direct vicinity of the mine, they do not show a clear attachment to individual phorophytes. Some of them occur even on the bark of Pinus characterised by acid reaction (cf. Cieśliński \& Jaworska, 1986; Cieśliński i Czyżewska, 1992; Loppi \& Pirintos, 2000). The impact of eutrophication of the bark of trees by the lime dust on the occurrence of epiphytic lichens was also described by e.g. Gilbert (1976) and Kortesharju \& Kortesharju (1989).

The relative abundance of threatened (to a varying extent) lichens proves the high natural value of the study area. Nine species from the Red List of Threatened Lichens in Poland (Cieśliński et al., 2006) were found in this area, including Enchylium coccophorum and Heppia adglutinata, classified as endangered species (EN), Bacidia rubella, Endocarpon pusillum and Goidanichia ambrosiana classified as vulnerable species (VU) and Lempholema chalazanum, Thelidium papulare and Th. incavatum classified as near threatened (NT). Furthermore, Thelidium rimosulum, known so far only from the described area as new to science, could be added to the Red List of Lichens in Poland.

On the regional scale and the scale of northern Poland, Verrucaria calciseda, Lecania erysibe, Protoblastenia rupestris and Verucaria obfuscans (rare in lowlands) as well as other species widespread in mountains and uplands of the southern part of the country should be included in the list of rare and endangered species.

\section{Conclusions}

The area of the discussed strip limestone mine represents an important habitat island for calciphilous lichen species in the Polish lowlands, located far from the limestone uplands and mountains. So far, 53 lichen taxa have been found there, which proves the taxonomic richness of the calciphile lichen biota, given the small area located in the lowlands of central Poland. The biota includes rare species from the Polish Red List of Threatened Lichens, growing far from their main distribution range. Due to the unique nature of this biota, further lichenological studies in the described area are needed.

\section{Acknowledgements}

We are very grateful to Dr. hab. Beata Krzewicka from the Polish Academy of Sciences in Kraków for verifying the identified material from the genus Verrucaria and making her own identifications.

We are also grateful to anonymous Reviewers for their valuable remarks and suggestions.

\section{References}

Adamska E., 2014, Biota porostów Torunia na tle warunków siedliskowych miasta [Lichen biota in Toruń in relation to habitat conditions of the city], Wyd. Naukowe UMK, Toruń.

Ceynowa-Giełdon M., 2001, Kalcyfilne porosty naziemne na Kujawach [Calciphilous terricolous lichens in $\mathrm{Ku}-$ jawy], Wyd. Naukowe UMK, Toruń.

Ceynowa-Giełdon M., 2007, Thelidium rimosulum (Verrucariaceae, lichenized Ascomycota), a new lichen species from Poland. The Lichenologist 39(3): 217-220.

Ceynowa-Giełdon M. \& Adamska E., 2014, Notes on the genus Thelidium (Verrucariaceae, lichenized Ascomycota) in the Kujawy region (north-central Poland. Ecological Questions 19: 25-33.

Ceynowa-Giełdon M., Adamska E. \& Kamiński D., 2004, Porosty w dolinie dolnej Wisły i na obszarze przemysłowym Kujaw [Lichens of the Lower Vistula and the Kujawy industrial area], [in:] E. Krasicka-Korczyńska, M. Korczyński (eds), Wycieczki geobotaniczne Region Kujawsko-Pomorski [Geobotanical excursions. The Kujawy-Pomerania Region], Bydgoszcz-Toruń: 13-22. Christensen S.N. \& Alstrup V., 2013, Notes on epilithic, epigeic and muscicolous lichens and lichenicolous fungi from rock outcrops in the mountains of northern Greece, Mycobiota 1: 25-50.

Cieśliński S. \& Czyżewska K., 1992, Problemy zagrożenia porostów w Polsce [Problems of threatened lichenized fungi in Poland],Wiad. Bot. 36(1-2): 5-17.

Cieśliński S., Czyżewska K. \& Fabiszewski J., 2006, Red list of the lichens in Poland, [in:] Z. Mirek, K. Zarzycki, W. Wojewoda, Z. Szeląg (eds), Red list of plants 
and fungi in Poland, W. Szafer Institute of Botany, Polish Academy of Sciences, Kraków: 71-89.

Cieśliński S. \& Jaworska E., 1986, Zmiany we florze porostów sosny (Pinus silvestris L.) pod wpływem emisji zakładów przemysłu cementowo-wapienniczego i wydobywczego [Changes in the lichenflora of pine (Pinus sylvestris L.) under the influence of the emission of an plant of cement industry and mining], Acta Mycol. 22(1): 3-14

Czajkowski B., 1969, Kronika Kujawskich Zakładów Przemysłu Wapienniczego w Bielawach koło Inowrocławia 1860-1967 [Chronicle of Kujawskie Zakłady Przemysłu Wapienniczego in Bielawy near Inowrocław], Kwartalnik Hist. Ruchu Zawod. 4: 56-74.

Fałtynowicz W., 1992, The lichens of Western Pomerania (NW Poland): An ecogeographical study, Polish Bot. Stud. 4: 1-182.

Fałtynowicz, W., 2003, The lichens, lichenicolous and allied fungi of Poland - an annotated checklist, W. Szafer Institute of Botany, Polish Academy of Sciences, Kraków.

Fałtynowicz W. \& Kossowska M., 2016, The lichens of Poland. A fourth checklist, Acta Botanica Silesiaca, ser. Monographiae 12, 8: 3-122.

Fahrig L., 2003, Effects of habitat fragmentation on biodiversity, Annual Review of Ecology Evolution and Systematics 34: 487-515.

Fischer J. \& Lindenmayer D.B., 2007, Landscape modification and habitat fragmentation: synthesis, Global Ecol. Biogeogr 16: 265-280.

Gilbert O. L., 1976, An alkaline dust effect on epiphytic lichens, The Lichenologist 8: 173-178.

Index Fungorum, 2016 [http://www.indexfungorum.org Accessed 2016-10-22].

Kondracki J., 2009, Geografia regionalna Polski [Regional geography of Poland], PWN, Warszawa.

Kortesharju M. \& Kortesharju J., 1989, Studies on epiphytic lichens and pine bark in the vicinity of a cement works in northern Finland, Silva Fennica 23(4): 301-310.

Kossowska M., 2008, Lichens growing on calcareous rocks in the Polish part of the Sudety Mountains, Acta Botanica Silesiaca Monographiae 3: 1-108.

Krzewicka, B., 2012, A revision of Verrucaria s.1. (Verrucariaceae) in Poland, Polish Botanical Studies 27: $1-143$.

Loppi S. \& Pirintsos S.A., 2000, Effect of dust on epiphytic lichen vegetation in the Mediterranean area (Italy and Greece), Israel Journal of Plant Sciences 48(2): 91-95.

Łubek A., 2007, Antropogeniczne przemiany bioty porostów Świętokrzyskiego Parku Narodowego i otuliny [Anthropogenic changes of lichen biota of the Świętokrzyski National Park and its protective zone], Fragmenta Flor. Geobot. Polonica. Suppl. 10: 3-94.
Nowak J., 1967, Porosty Wyżyny Wieluńskiej [The Lichens of the Wielun Upland], Acta Mycol. 3: 209-242.

Nowak J. \& Tobolewski Z., 1975, Porosty polskie [The lichen flora of Poland], Państwowe Wydawnictwo Naukowe, Warszawa-Kraków.

Olech M., 1985, Zbiorowiska porostów w wysokogórskich murawach nawapiennych w Tatrach Zachodnich [Lichen communities in alpine calcareous grasslands in the Western Tatra Mts.], Uniw. Jagielloński. Rozpr. Habilitacyjne 90: 5-132.

Otálora M.A.G., Jørgensen P.M. \& Wedin M., 2014, A revised generic classification of the jelly lichens, Collemataceae, Fungal Diversity 64: 275-293.

Passendorfer E. \& Wilczyński A., 1961, Przewodnik geologiczny po Kujawach i Pomorzu [Kujawy and Pomerania geological guide], Wydawnictwa Geologiczne, Warszawa.

Pietrzykowska K. \& Kossowska M., 2010, Porosty antropogenicznych podłoży wapiennych wokół schronisk górskich w polskiej części Karkonoszy [Lichens of anthropogenic calcareous substrates in surroundings of mountains shelter-houses in Polish part of Karkonosze Mts.], Fragmenta Floristica et Geobotanica Polonica 17(1): 141-147.

Purvis, O. W., Coppins, B. J., Hawksworth, D. L., James, P.W. \& Moore, D.M.,1999, The lichen flora of Great Britain and Ireland, Natural History Museum Publications in association with The British Lichen Society, London.

Sągin B., 1998, Porosty wapiennych podłoży pochodzenia antropogenicznego, Praca doktorska [The lichen of the calcareous substrates of anthropogenic origin, Doctoral Thesis], Katedra Ekologii i Ochrony Przyrody Uniwersytetu Gdańskiego, Gdańsk.

Servít M., 1954, Lichenes Familiae Verrucariacearum, Nakladatelstwi Československé Akademie Věd., Praha.

Smith C. W., Aptroot A., Coppins B. J., Fletcher A., Gilbert O. L., James P. W. \& Wolseley P. A., 2009, The lichens of Great Britain and Ireland, British Lichen Society, London.

Szczepańska K., 2008, Antropogeniczne przemiany bioty porostów Masywu Śnieżnika i Gór Bialskich [Anthropogenic changes of lichen biota of Śnieżnik Massif and Bialskie Mountains], Acta Botanica Silesiaca Monographiae 4: 1-291.

Tobolewski Z., 1958, Porosty Pienin [The Lichen Flora in the Pieniny], Prace Komis. Biol. Pozn. Tow. Przyj. Nauk 17(5): 1-124.

Wirth V., 1995, Flechtenflora. Bestimmung und ökologische Kennzeichnung der Flechten Südwestdeutschlands und angrenzender Gebiete. 2 Aufl. Stuttgart. Verl. E. Ulmer.

Zając A., 1978, Atlas of distribution of vascular plants in Poland ATPOL, Taxon 27(5-6): 481-484. 